\title{
Reinterpretasi Mazmur 23 sebagai Teks Quantum Affirmasi Healing
}

Yudhi Kawangung ${ }^{1}$ Nelci Nafalia Ndolu², Munatar Kause ${ }^{3}$

1,3Sekolah Tinggi Agama Kristen Teruna Bhakti, Yogyakarta

2Institut Agama Kristen Negeri Kupang, Nusa Tenggara Timur

1ykawangung06@gmail.com,2nelcinafaliandolu@gmail.com,3munatarmoses@gmail.com

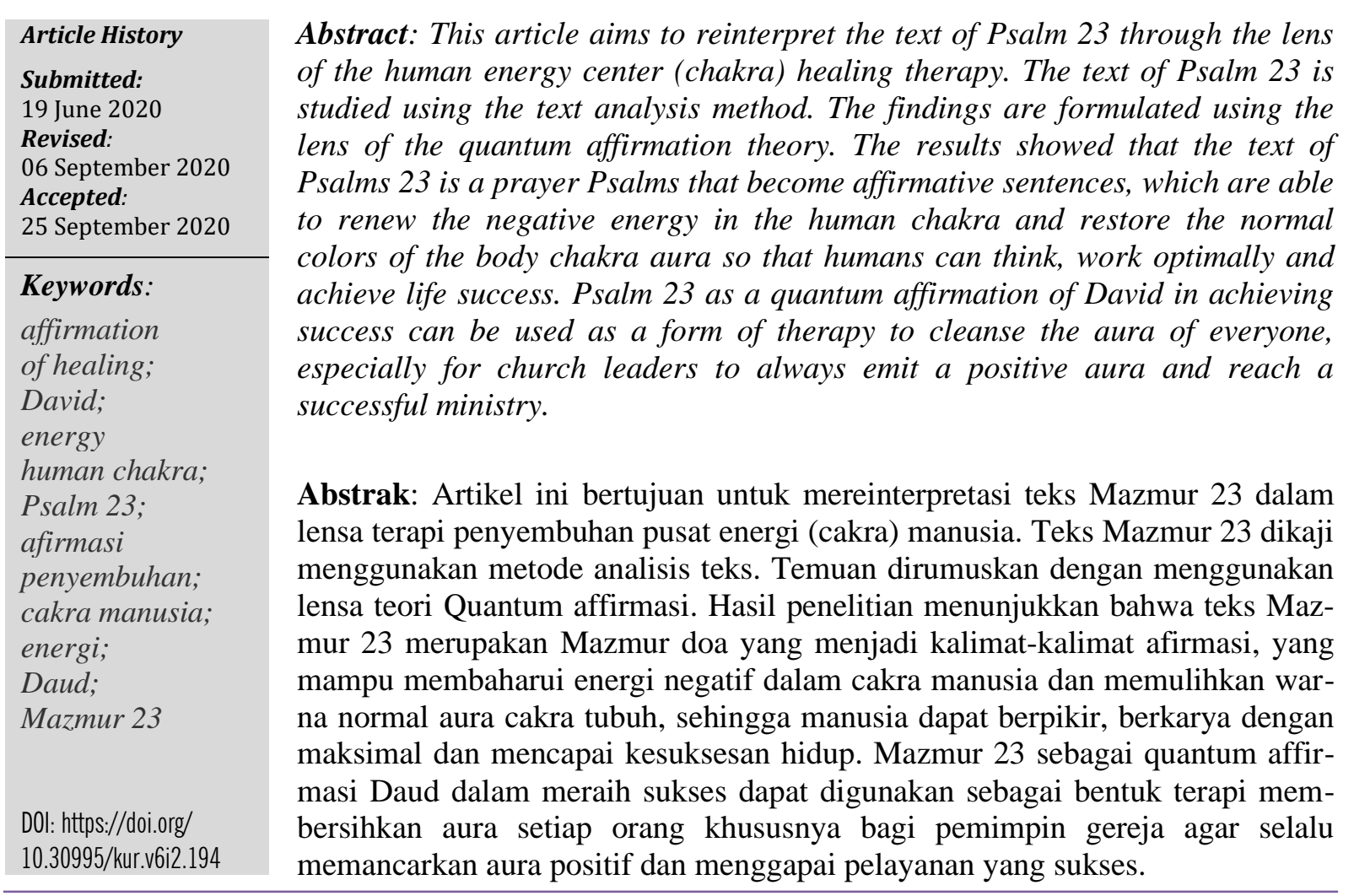

\section{Pendahuluan}

Secara umum penafsir menandai Mazmur 23:-1-6 sebagai teks penggembalaan. Teks Mazmur diteliti dengan memberikan higlight eksistensi Allah sebagaimana Gembala yang agung yang mencipta, memelihara dan melindungi manusia. ${ }^{1}$ Secara khusus, Dag Heward-Mills memberi uraian rinci tentang tuntunan bagi pendeta dalam menjalankan perannya sebagai gembala jemaat. Seorang pendeta patut menggembalakan umat dengan berkhotbah, mengajar dan menyembuhkan umat secara lahir dan batin. ${ }^{2}$ Dengan demikian, Mazmur 23 ini lebih fokus digunakan sebagai teks untuk mendidik pendeta dalam menjalankan tugas dan tanggung jawabnya sebagai gembala.

${ }^{1}$ Victor P Hamilton, "The Shepherd Psalm: Psalm 23" Journal Biblical Literature LXV, No. 3,(1966), 13 24;. Marie. Claire Barth B. A. Pareira \&, Tafsiran Alkitab: Kitab Mazmur 1-72 (Jakarta: BPK Gunung Mulia, 2008), 190-196,W. Creighton Marlowe, "No Fear!: Psalm 23 As A Careful, Conceptual Chiasm," The Asburry Theological Journal 7, No. 1 (2003): 497-516..

${ }^{2}$ Dag Heward Mills, The Art of Sherperding (America: Lux Verbi.BM, 2010), 10-20. 
Gerstenberger pernah menyebut Mazmur 23 sebagai song of confidence, dengan membagi Mazmur 23 menjadi tiga bagian yakni confessional statement (ayat 1-3), Affirmation of confidence (4-5), dan expression of hope (ayat 6). ${ }^{3}$ Artinya, Gerstenberger telah melihat ada kecenderungan teks Mazmur 23 sebagai teks afirmasi penyembuhan. Dalam tulisan ini, teks Mazmur dilihat secara mendalam sebagai teks kuantum afirmasi penyembuhan dari Daud yang menambah getaran energi kepada setiap pusat cakranya sehingga menjadikan pribadi yang tangguh dan sukses. Penelitian ini dilakukan dengan memperhatikan konsep bahwa segala hal adalah energi. ${ }^{4}$ Energi berasal dari pikiran, niat dan perkataan seseorang. Energi adalah aspek penting yang mempengaruhi tubuh halus atau cakra dan aura manusia yang turut menentukan perilaku, sikap, tindakannya sehari-hari sehingga mencapai kesuksesan.

Cakra manusia adalah tempat energi manusia yang memiliki peran dan tugas masingmasing. Setiap cakra manusia tersebut memiliki warna yang biasa disebut aura. Ada tujuh cakra manusia yakni cakra dasar yang memiliki warna merah, cakra sakral yang berwarna jingga, cakra solar pleksus berwarna kuning, cakra jantung berwarna hijau, cakra tenggorokan berwarna biru, cakra mata bathin berwana nila dan cakra makhota berwarna Ungu. ${ }^{5}$ Cakra dasar merupakan tempat pusat kemampuan dimensi tubuh fisik. Cakra sakral sebagai pusat emosi manusia. Cakra jantung merupakan tempat pusat pikiran dan tempat berdiamnya energi cinta kasih. Cakra tenggorokan menjadi tempat pusat energi ekspresi. Cakra mata batin berkaitan dengan kemampuan imajinasi dan alam bawah sadar manusia. Sedangkan cakra mahkota mengatur kemampuan koneksi dengan Tuhan dan alam semesta.

Cakra-cakra tersebut ada kecenderungan untuk bisa bersih dan kotor karena sikap dan perilaku setiap orang dengan lingkungan. Pada dasarnya cakra tersebut bersih sejak lahir dengan warna yang terang namun cakra tersebut punya kecenderungan untuk kotor ketika seseorang mendapat perlakuan negatif dari sesama. Bagian aura yang kotor disebut sebagai black body. ${ }^{6}$ Black body merupakan partikel negatif dari emosi negatif orang atau lingkungan. Bila cakra manusia tersebut terang maka ada energi positif tersimpan dalam tubuh halus manusia tersebut dan berfungsi dengan baik sebagaimana yang nampak dalam sikap dan perilaku nyata yang positif pula serta hidup yang berhasil dan sukses. Demikian pula bila ada penyumbatan atau warna aura kotor tentu ada energi yang negatif yang tersimpan dan menyumbat energy baik dalam dalam cakra manusia sehingga membuat individu tersebut tidak dapat melaksanakan potensinya dengan baik.

Pembersihan warna aura sangat penting sehingga individu dapat mengoptimalkan kompetensinya. Teknik sederhana yang dapat dilakukan adalah afirmasi secara lisan kalimat-kalimat positif yang berenergi yang mampu meningkatkan getaran energi tubuh. Kalimat-kalimat afirmasi positif berisi tentang kekuatan diri, kekuatan alam semesta, dan kekuatan Tuhan.

${ }^{3}$ Erhard S. Gerstenberger, Psalms, Part I with an Introduction to Cultic Poetry. The Forms of Old Testament Literature. Vol. 14. (Grand Rapids: Wm. B. Eerdmans Publishing Co, 1988), 113-115.

${ }^{4}$ Jhon Murphy, The Study of Science Physics : Understanding The Properties of Matter and Energy (New York: Britannica Educational Publishing \& Rosen Publishing, 2015).Niko Tesla, The Problem of Increasing Human Energy (New York: Cosimi, Inc, 2013).

${ }_{5}^{5}$ Deanna M. Minnich, The Complete Handbook of Quantum Healing : An A-Z Self Healing Guide for Over 100 Common Ailments (America: Red Wheel Weiser, 2011). King Gunawan, Melalui Aura Kenali Potensi Sukses Anda Dalam 10 Detik (Jakarta: PT Elex Media Komputindo, 2010)..

${ }^{6}$ Stephen Sontsz Bruce, An Introductory Path to Quantum (Mexico: Springers, 2020). 
Tujuannya adalah membersihkan pusat cakra manusia dari energi negatif yang menumpuk dalam cakra manusia sehingga membuat manusia tidak dapat berpikir, berkarya, dan sehat sebagaiama mestinya untuk mencipta masa depan yang sukses. Seperti usulan bahwa Mazmur 23 merupakan quantum affirmasi healing Daud dalam mengoptimalkan cakra-cakra tubuhnya sehingga ia memiliki warna aura yang terang benderang yang mewujud dalam eksistensinya sebagai raja yang sukses dalam sejarah Israel kuno, maka teks ini akan dikaji untuk menampilkan spirit penyembuhan yang terkandung dalam kalimat-kalimat tersebut untuk penyembuhan jiwa atau reiki alkitabiah yang dilakukan oleh Daud. Tujuan penelitian ini adalah memberikan metode reiki alkitabiah bagi setiap orang yang berusaha memiliki soul meter yang baik sehingga bisa hidup dengan damai dan sukses. Dengan demikian setiap individu mengalami hidup yang damai, tenang, bahagia setiap hari dalam berbagai tantangan dan kondisi kehidupan yang terjadi.

\section{Metode Penelitian}

Teks Mazmur 23: 1-6 yang menjadi titik kajian dalam artikel ini dideskripsikan menggunakan metode analis teks. Secara umum, metode analisis teks mencakup uraian kata kunci setiap ayat untuk menguak keluar makna teks dalam Biblia Hebraica Sturtgantsia (BHS) sesuai pembaca teks saat itu yang sekiranya menjadi bahan refleksi bagi kehidupan pembaca saat ini. ${ }^{7}$ Uraian kata kunci setiap ayat dianalisis dengan bantuan aplikasi Bibleworks ${ }^{7}$. Setiap kata kunci sebagaimana yang tertulis dalam Biblia Hebraica Sturtgantsia (BHS) ditinjau ulang dengan memperhatikan dengan jenis kata, dan arti kata arti itu secara keseluruhan melalui penggunaannya dalam bahasa Ibrani kuno. Tahap selanjutnya, arti teks ditetapkan dengan memperhatikan sintaksis teks tersebut. Selanjutnya, arti teks di rumuskan dengan mengacu pada konteks konsep kuantum afirmasi penyembuhan.

\section{Pembahasan}

\section{Mazmur 23:1}

Kata Mazmur (mizmor) adalah kata benda maskulin tunggal dari akar kata zemor. Dalam bahasa Inggris diartikan psalms yang mengandung arti mazmur, pujian, nyanyian dan melodi. Penggunaan kata mazmur merujuk arti "suatu gubahan yang berlagu". 8 Secara tradisional kebanyakan Mazmur dalam Perjanjian Lama dikonstruksi sebagai ciptaan raja Daud. ${ }^{9}$ Ungkapan Mazmur Daud (le-Dawid) yang mempunyai arti "dari Daud" sebagai judul dan dalam teks aslinya merupakan bagian dari ayat satu. Tentang Daud menulis banyak Mazmur sering diperdebatkan, dengan alasan utama bahwa Daud pemazmur tidak cocok dengan Daud prajurit yang diuraikan dalam Samuel dan Raja-Raja ${ }^{10}$.

Kemudian kata selanjutnya dalam ayat satu adalah "TUHAN adalah gembalaku tak menjadi kurang aku." Pemazmur menggunakan sebutan YAHWEH yang menunjuk eksistensi TUHAN sebagai penguasa seluruh kerajaan di dunia dan raja dari segala ilah di Kanaan,

\footnotetext{
${ }^{7}$ A.A. Sitompul. \& Ulrich Beyer, Metode Penafsiran Alkitab (Jakarta: BPK Gunung Mulia, 2015), 33-60.

${ }^{8}$ Clarence H. Benson, Pengantar Perjanjian Lama-Puisi Dan Nubuat"'(Ayub-Maleakhi (Malang: Penerbit Gandum Mas, 1983).

${ }^{9}$ J.L. Ch Abineno, Mazmur Dan Ibadah (Jakarta: BPK Gunung Mulia, 1991), 114.

${ }^{10}$ Douglas, Ensiklopedi Alkitab Masa Kini,42.
} 
Mesopotamia, Asyur, Babel, Mesir. ${ }^{11}$ TUHAN dalam kemampuan berkata/ berbicara, bekerja, melihat, mendengar berjumpa dan bergumul dengan manusia serta berbela rasa dengan manusia digambarkan sebagai gembala pemazmur. ${ }^{12}$ Ia adalah TUHAN yang melindungi. Ia adalah gembala yang melindungi pemazmur. Pada zaman dulu gambaran tentang gembala dipakai untuk raja-raja dan dewa-dewa. Raja Hammurabi menyebut dirinya sebagai gembala. Dewa keadilan Babilonia, Shamesh disebut juga sebagai gembala. ${ }^{13}$ Raja sebagai gembala, berarti memelihara rakyatnya, demikian juga kalau dewa disebut sebagai gembala, maka dewa itu dipercaya memelihara umatnya. Metafora ini pun dipakai untuk TUHAN Israel, yang menunjukkan hubungan antara TUHAN dengan anak-anak perjanjianNya (band. Mzm. 74:1-4; 77:20; 78:52, 70-72; 79:13; 80:1; Yes.40:11; Mik.7:14). Allah yang akan memelihara umatNya, sehingga umatnya tidak kekurangan. Ini merupakan suatu keyakinan atas jaminan tersebut. Frasa "Tak menjadi kurang aku" (lo ekhesar) lebih mudah untuk dimengerti sebagai tidak akan miskin, mengandung penekanan terjamin dalam keadaan tidak berkekurangan makan dan minum (Kej.8:3-5; 18:28; Ul 2:7; 1Raj. 17:1).

Dalam Mazmur 23 ini, memakai kata "ku", yang menyatakan bahwa pemazmur memiliki hubungan pribadi dengan TUHAN. Mazmur ini menjadi sangat terkenal, karena setiap orang percaya dapat memakai kata-kata dalam mazmur untuk menyatakan keyakinannya bahwa TUHAN perjanjian juga mengasihinya dan menjadi gembala mereka. Coba perhatikan kata "aku" di dalam mazmur ini, ayat 1-4. Dari ayat 1-4 penuh dengan kata "aku". Oleh sebab itu ketika menyanyikan mazmur 23 ini, akan sangat menyentuh perasaan. Mazmur 23 ayat 16 berbicara mengenai jaminan baik secara jasmani, jiwani dan rohani; jaminan yang diberikan selama di dunia sampai kepada kekekalan nanti.

Berdasarkan pemaparan di atas dapat dipahami jika seandainya bukan Raja Daud yang menulis Mazmur ini; namun yang dapat dipastikan pemazmur adalah seorang penggem-bala yang memahami dengan benar keberadaannya, dalam artian tugas dan tanggung jawab-nya. Keberadaanya memastikan kawanan domba yang digembalakan dalam kondisi yang baik dari sisi makanan, minuman, maupun keamanan. Raja Daud disinyalir sebagai penulisnya bisa dipertimbangkan juga, oleh karena pengalamannya sebagai gembala (domba) bisa dijadikan alasan yang cukup konkrit ditambah dengan kepiawaiannya dalam bernyanyi (bermazmur).

Analogi Tuhan sebagai gembala banyak sekali mewarnai teks Kitab Suci, sehingga citra gembala dalam arti tugas dan tanggung jawabnya sangat relevan jika ditransformasikan ke dalam relasi antara Tuhan dengan manusia. Sebagaimana gembala menjaga, melindungi dan memastikan kebutuhan dombanya, demikian juga dengan Tuhan terhadap umatNya. Bahkan pemeliharaan Tuhan terhadap umat tidak hanya bersifat komunal bahkan secara epik personal ditunjukkan dalam kalimat pemazmur yang mengunakan kata ganti orang pertama (-ku; aku).

\footnotetext{
${ }^{11}$ Michael S Heiser, "Does Divine In The Hebrew Bible Demonstrate an Evolution From Polytheism to Monotheism in Israel Religion," JESOT 1, No. 1 (2012): 1-20,

https://books.google.co.id/books?id=czfnawaaqbaj\&pg=pa16\&lpg=pa16\&dq=yahweh+journal+old+testament\& source $=$ bl\&ots $=0 \mathrm{~b}-$

v0888rz\&sig=acfu3u0fw0tyv3jf1 fnrfymdw5f8ulfyng\&hl=id\&sa=x\&ved=2ahukewir5p6q8_7pahwexsskhfiralyq 6 aewexoecacqaq $\# \mathrm{v}=$ onepage $\& \mathrm{q}=\mathrm{yahweh}$ journal old testament $\& \mathrm{f}=$ false.

${ }^{12}$ Walter J. Houston, "The Character of Yhwh and the Ethics of the Old Testament: Is Imitatio Dei Appropriate?," Journal of Theological Studies 58, No. 1 (2007): 1-25.

${ }^{13}$ Frans W. Gaebelein, The Expositor to Bible Commentary Vol. V,215.
} 
Kata terindah dari keseluruhan suku kata adalah "aku", pemazmur tidak berkata, "Tuhan adalah gembala dunia dan memimpin orang banyak sebagai kawanannya," tetapi dengan kalimat "Tuhan adalah gembalaku." "14 Jelas sekali Tuhan sebagai gembala memiliki relasi erat dengan umat antar pribadi, jalinan.

\section{Mazmur 23:2-3a}

Sebagai Gembala, TUHAN membaringkan umatnya di padang yang berumput hijau. Kata nawah merujuk kepada situasi padang yang dipenuhi dengan padang rumput hijau hijau. Dalam Yeremia 5:37 dijelaskan padang rumput yang sentosa yang berarti bebas dari segala kesukaran dan bencana, aman dan tenteram, sejahtera. Kata ini juga paralel dengan kandang domba yang penuh dengan rumput hijau (Yes.33:20). Menurut Hamilton metafora padang rumput mengindikasikan kondisi tanah Kanaan yang subur yang dapat menghasilkan gandum, jelai yang dapat dibuat roti, serta menumbuhkan buah-buahan seperti anggur sebagai komoditas ekonomi unggul. ${ }^{15}$ Pemazmur juga menyatakan bahwa Tuhan membimbing ke air yang tenang. Tindakan membimbing merupakan kata kerja yang menggambarkan bahwa Allah menyetir kehidupan umat-Nya dalam memenuhi kebutuhan dasar manusia untuk hidup, seperti bertani dan berternak yakni air. Inilah yang selalu dicari oleh manusia, padang rumput hijau dan air yang tenang. Ketika berada di padang hijau, domba-domba memiliki waktu untuk istirahat, dan gembala membaringkan mereka. Di air yang tenang, domba-domba dapat minum dengan tenang. Padang rumput yang hijau dan air yang tenang menggambarkan pemeliharaan yang menyegarkan dari Allah untuk domba-dombaNya.

Frasa "Ia menyegarkanku jiwaku" menunjuk pada perawatan jiwa pemazmur. Peacock menerjemahkan jiwa (nepesy) sebagai keinginan/hasrat, pusat perasaan dan pikiran manusia, gairah hidup. ${ }^{16}$ Aspek-aspek tersebut disebut sebagai "jiwa" yang merupakan bagian terpi-sah dari tubuh. Terjemahan nepesy dalam arti "jiwa" bersesuaian dengan terjemahan LXX, ASV, KJV, NRSV. Richard Pleijel menerjemahkannya sebagai semangat (spirit) dan bathin (inner person $)^{17}$. Pendapat tersebut mendukung terjemahan CJB yang menejemakan kata nepesy dengan kata inner person, dan terjemahan NJB' 'spirit'. Dalam konteks jiwa pemazmur yang multidimensi tentu keseluruhan terjemahan tersebut tercakup di dalamnya. Dengan demikian pernyataan pemazmur tersebut mengadung pemahaman bahwa Tuhan mampu memulihkan (ASV, KJV, NRSV, CJB, NJB) keinginan, hasrat, gairah, semangat hidupnya di bagian pusat cakra manusia yang mengatur pikiran dan perasaan manusia. Ada tindakan pembaharuan sistem terdalam dari pikiran dan perasaan manusia.

Berdasarkan uraian di atas menampilkan sosok Tuhan dengan citra gembala yang menuntun dombanya ke hamparan rumput hijau agar kawanan domba bisa dengan lahap makan hingga kenyang tanpa ada kekuatiran kekurangan. Demikian juga dengan Tuhan terhadap pemazmur akan dibawa kepada kesejahteraan dan ketenteraman. Namun, perlu diingat di sana

\footnotetext{
${ }^{14}$ Charles H. Spurgeon's, The LORD as Shepherd sustains, https://enduringword.com/biblecommentary/psalm-23/ didownload tanggal 12 September 2020 jam 23.00 WIB.

${ }^{15}$ Victor P Hamilton, "The Shepherd Psalm: Psalm 23" (1966),5-11.

${ }^{16}$ Heber F Peacock, "“Translating the Word for "Soul” in the Old Testament.,", The Bible Translator 27, No. 2 (1976): 216-219.

${ }^{17}$ Richard Pleijel, " Translating the Biblical Hebrew Word Nephesh in Light of New Research ," The Bible Translator 70, No. 2 (2019): 154-166.
} 
Tuhan membawa sehingga ada suatu proses perjalanan menuju ke hal tersebut. Kadang pemazmur lupa dan tidak mau masuk dalam prosesnya dan ingin suatu yang instan, padahal dalam perspektif penulis kesentosaan (sejahtera dan tenteram) bukan fokus kelangsungan hidup umat akan tetapi sumber pemberilah yang jadi orientasi umat sepanjang masa dan abad yaitu Tuhan Sang Gembala.

Sang Sumber Pemberi juga menyegarkan jiwa umat tidak hanya kesentosaan (sejahtera dan tenteram), namun jiwa yang bersentuhan dengan perasaan pun selalu diperhatikanNya. Pada saat umat dalam keterkalutan Tuhan sebagai gembala akan memulihkan keadaan jiwanya oleh desakan kehidupan yang dinamis, menyegarkan jiwa merupakan sebuah ungkapan pemulihan batin yang dirasakan oleh umat. Kekosongan jiwa tidak dapat diisi oleh yang sifatnya materialistis, tetapi lebih pada memulihkan batin sehingga jiwa kembali sediakala, yang artinya muncul semangat, hasrat dan asa dalam melanjutkan perjalanan proses kehidupan. Manusia, walaupun memiliki kebutuhan dan keperluan yang memadai bahkan melimpah, tentu belum secure jika sisi jiwaninya masih diliputi oleh berbagai banyak problematika yang berimplikasi pada ketidakstabilan emosi. Jiwa Daud dipulihkan, dengan kiasan atau digambarkan seumpama padang rumput hijau dan air tenang yang dibawa gembala kepadanya. ${ }^{18}$ Maka Tuhan menganugerahkan ketenangan emosi jiwa yang mewujudnyata dalam kejernihan pikiran dan kedewasaan perasaan setiap menghadapi dinamika kehidupan psikososial dalam diri dan umat lainnya.

\section{Maz. 23:3b-4}

Selanjutnya, pemazmur menyatakan bahwa Tuhan mampu menuntunnya ke jalan yang benar. Jalan yang benar (bema'gele tsedeq) merujuk pada sikap yang tidak merugikan, merusak, menyalahi hukum moral. Sikap yang dimaksud digambarkan dalam Mazmur 22:25; 24:4, yakni tidak memandang hina atau jijik kepada orang miskin, tetapi justru membantu mereka, tidak menipu hak setiap orang dan bersumpah palsu. ${ }^{19}$ Sikap welas yang menjadi ciri tingkat spiritualitas yang tinggi dapat dimiliki bila mengafirmasi energi positif dari Tuhan. ${ }^{20}$

Ayat 4 berbunyi, "Sekalipun aku berjalan dalam lembah kekelaman." Domba-domba suatu waktu akan melalui lembah kekelaman. Frasa "dalam lembah kekelaman" (begey tsalmawet) ini bisa diterjemahkan sebagai bayangan kematian, atau kegelapan yang sangat gelap, kegelapan yang sangat dalam. Frans menjelaskan lembah kekelaman menunjuk kepada jurang dari wadi yang berada pada lereng sempit yang tersembunyi dari cahaya yang terang. ${ }^{21}$ Robert Jamiesen mengemukakan lembah bayang-bayang merujuk jurang dengan ketinggian yang terjal yang berisikan hutan belukar yang menutup sehingga mengilhamkan ketakutan yang tak terhitung, memberikan kemampuan binatang untuk memangsa, suatu bahaya yang besar dan menimbulkan ancaman ketakutan atau teror. ${ }^{22}$ Tetapi Tuhan akan membawa umatNya "melewatinya", ini berarti bahwa seringkali rencana Tuhan menginginkan umat-Nya untuk berjalan melewati saat yang sulit, menghadapi bayang-bayang kekelaman dan tempat-

\footnotetext{
${ }^{18}$ Kidner and Boice, The LORD as Shepherd leads, https://enduringword.com/bible-commentary/psalm23/ didownload tanggal 12 September 2020 jam 23.00 WIB.

${ }^{19}$ Ellen T. Charry, Psalms 1-50 (Whasinton: Brazos Press, 2015).

${ }^{20}$ Duncan Heaster, Psalm 1-80: A Commentary (Australia: Carelinks, 2018), 140-144.

${ }^{21}$ Ibid., 216-217.

${ }^{22}$ Robert Jamieson, "Commentary Practical and Explanatory On The Whole Bible., 214"
} 
tempat yang gelap di dalam hidup umatNya. Namun demikian, di tengah kesulitan, umat tetap menunjukkan atensinya kepada Tuhan yang memimpin hingga mampu mengurai tiap kesulitan yang dihadapi.

Domba-domba suatu waktu akan berjalan melalui kegelapan yang sangat pekat ini. ${ }^{23}$ Ketika gembala memimpin domba-dombanya, kadang-kadang pulangnya malam, maka seorang gembala yang baik mengetahui jalan yang benar yang akan membawa kembali domba-dombanya pulang kekandang dengan aman ${ }^{24}$, sehingga mereka akan berjalan dalam kegelapan malam; tetapi kegelapan yang dimaksud ini pun dapat dialami pada siang hari. Meskipun betapa panjang dan suramnya lembah kekelaman itu, domba masih tetap memiliki bimbingan dan perlindungan dari sang gembala. ${ }^{25}$ Pada saat gembala menuntun domba-dombanya mencari padang rumput, mereka akan melalui jurang dan lembah, di mana lereng yang curam dan sempit akan menghalangi sinar, sehingga domba-domba akan melalui jalan yang gelap. Domba-domba tidak takut, walapun berjalan dalam kegelapan seperti itu, sebab gembalanya sedang menuntun mereka di jalan yang benar.

Sama halnya dengan pemazmur, lembah kegelapan menyatakan bahwa hidupnya tidak tentu. Apa yang ada di depan, pemazmur tidaklah tahu; jalan apa yang akan dilalui tidaklah diketahui. Bisa berjalan dalam terang, dan dapat juga berjalan dalam gelap hidup, mengalami terang dan gelap silih berganti. Sukses dan gagal silih berganti, sakit dan sehat silih berganti. Pada saat manusia berada dalam gelap, manusia bertanya di manakah Tuhan? Walaupun berada dalam lembah kekelaman, tapi tetap bisa berjalan di jalan yang benar, oleh karena Tuhan bersertanya. Gembala yang memimpin domba-dombaNya, akan selalu bersama-sama dengan domba-dombaNya. Kehadiran dan pimpinan dari Tuhan akan berjalan beriringan. Jadi Tuhan hadir dalam hidup dan memimpin. Ia terikat oleh karena nama-Nya, Imanuel, hadir bersama-sama dengan umat-Nya. Demi namaNya, Ia akan memelihara semua janji-janji-Nya kepada anak-anak perjanjian (band. 25:11; 31:3; 79:9; 106:8; 109:21; 143:11; Yes. 48:9; Yeh. 20:44). Ia setia kepada umatNya.

Sifat pemeliharaanNya terletak pada perlindungan yang Ia berikan (Mzm. 23:4c). ${ }^{26}$ Terkadang berada di padang rumput, akan tetapi juga ada di dalam lembah kekelaman. Padang rumput dan air yang tenang memang musiman, akan tetapi perhatian dari gembala tidaklah musiman, tetapi konstan dan fokus. Demikian jugalah hidup pemazmur, pemeliharaan dan kebaikan Allah tidaklah musiman, tetapi konstan dan fokus. Tuhan tidak pernah meninggalkan seekor dombaNya. ${ }^{27}$ Pemazmur mengalami masa-masa sulit dan senang, akan tetapi dalam setiap masa Tuhan tetap memelihara umat-Nya. Pemeliharaan melalui perhatian gembala yang dilambangkan dengan gada atau tongkat. ${ }^{28}$ Perhatian gembala juga disimbolkan

${ }^{23}$ D. W. Thomas, ""Salmawet in the Old Testament," " Journal of Semitic Studies XXII, No. 1 (1962): 1991.

${ }^{24}$ John F. Walvoord and Roy B. Zuck, The Bible Knowledge Commentary (USA-Canada-England: Victor Book House, 1978),9.

${ }^{25}$ H. Spence, and Joseph S. E Excell, The Pulpit Commentary, Vol. VIII, 10.

${ }^{26}$ Gaebelein, The Expositor to Bible Commentary Vol. V.

${ }^{27}$ John F. Walvoord and Roy B. Zuck, The Bible Knowledge Commentary, 7.

${ }^{28}$ Gaebelein, The Expositor to Bible Commentary Vol. V. 
dengan gada dan tongkat. Istilah gada dan tongkat yang dipertimbangkan adalah lambang dari pekerjaan gembala, dengan alat-alat itu Ia membawa domba-dombaNya. ${ }^{29}$

Seorang gembala membawa gada untuk menghalau binatang atau hewan liar dan buas (1Sam. 17:43; 2Sam. 23:21). Sedangkan tongkat digunakan untuk mengarahkan serta menjaga supaya tetap dalam kendalinya. Bimbingan dan kepemimpinanNya mengikuti langkahlangkah penggembalaanNya, penjagaanNya dari kejahatan. ${ }^{30}$ Selain itu gada dan tongkat adalah kekuatan serta kuasa penggembalaan dan pertahanan; itulah yang selalu memberi penghiburan. Dengan demikian gada dan tongkat memberi makna sebagai lambang dari kehadiran, perlindungan dan bimbinganNya. Allah membimbing dan melindungi pemazmur melewati berbagai permasalahan yang ada. Pemazmur bersukacita karena Tuhan seperti seorang gembala di dalam ketetapan perlindungan dan bimbingan-Nya sehingga tidak timbul ketakutan. Gada dan tongkat memberi makna sebagai lambang dari kehadiran, perlindungan dan bimbingan Tuhan. Kebaikan dan belas kasihan akan mengikuti pe-mazmur sepanjang hari dalam hidupnya. ${ }^{31}$ Ringkasan dari sebab peran penggembalaan diung-kapkan dalam kata ganti orang pertama; Aku tidak akan kekurangan, aku tidak takut bahaya (Mzm. 23:1, 4).

Jika domba mencari padang rumput hijau dan air yang tenang, maka pemazmur pun mencari sebuah keadaan hidup yang seperti itu. Sebuah kehidupan yang baik dan layak. Hidup yang baik dan layak tentunya tidak harus kaya raya. Hidup yang baik dan layak adalah tidak kekurangan seperti yang dikatakan di ayat satu, dan tetap berada di jalan yang benar, seperti yang dituliskan dalam ayat tiga. Inilah dua ukuran tentang hidup yang digembalakan oleh Tuhan. Hidup yang baik dan layak dan tetap berada di jalan yang benar. Tuhan, sebagai gembala, memberikan kepada pemazmur sukses dalam arti sebuah kehidupan yang baik, layak, tidak kekurangan dan tetap berada di jalan yang benar. Sama halnya, gembala memberikan domba-dombanya istirahat, padang rumput hijau, dan air tenang, maka Tuhan pun memelihara pemazmur dengan cara yang paling berlimpah. Air tenang adalah sumur atau mata air dimana domba-domba dapat minum tanpa diganggu (band. Yes. 32:18). ${ }^{32}$ Ia selalu memperbaharui mereka sehingga mereka merasa bahwa hidup di dalam kehadiran Tuhan adalah baik dan layak.

Namun ada sesuatu hal lagi yang menarik dari padang rumput dan air yang tenang ini. Padang rumput hijau dan air yang tenang adalah sebuah keadaan yang musiman. Rumput akan hijau selama musim semi dan musim dingin, tetapi pada saat musim panas dan musim rontok, maka padang rumput yang hijau sangat sulit ditemukan. Untuk itu gembala akan menuntun domba-dombanya mencari padang rumput yang lain. Dan dalam pencarian padang rumput ini akan melewati gunung yang terjal, lembah dan tempat-tempat yang berbahaya. Oleh sebab itu ketika ayat satu dituliskan, bahwa gembalaKu membaringkan aku di padang

\footnotetext{
${ }^{29}$ Robert Jamieson, “Commentary Practical and Explanatory On The Whole Bible” (Michigan: The Zondervan Publising House, 1978),416.

${ }^{30}$ H.Spence and Joseph S. Exell, The Pulpit Commentary, Vol. VIII (Michigan, Grand Rapids: Eerdsmans Publishing, 1977),10.

${ }^{31}$ Charles H. Spurgeon's, Treasury of David, https://www.christianity.com/bible/commentary.php?com=spur\&b=19\&c=23 didownload tanggal 12 September 2020 jam 23.15 WIB.

${ }^{32}$ Gaebelein, The Expositor to Bible Commentary Vol. V,216.
} 
rumput hijau maka itu adalah sebuah keadaan yang sementara; tidak selama-lamanya ada di padang rumput hijau. Akan ada lembah, gunung, tempat kering yang harus dilalui. Kadangkadang jalan di tempat terang tetapi tidak jarang pula jalan di tempat yang gelap bahkan sangat gelap dan menyeramkan sekali, akan tetapi Tuhan tetap selalu bersama menyertai perjalanan pemazmur.

\section{Maz. 23:5}

Pemazmur menyatakan bahwa TUHAN menyediakan (arok) hidangan di hadapan lawannya. Gabelein menjelaskan bahwa lawan-lawan pemazmur adalah orang-oramg yang membuat pemazmur mengalami kesengsaraan dalam hidup. ${ }^{33}$ Sedangkan Hobb dan Jackson menyebut musuh dalam kitab mazmur mencakup bangsa non-Israel yang tidak menyembah Allah dan berusaha untuk membuat orang Israel tidak setia beribadah kepada Allah; penipu, pejahat yang menusuk dari belakang, orang yang menajiskan Bait Allah, raja dan tentaranya yang ingin menguasai kerajaan Israel secara politik dan menjajah Israel secara ekonomi. ${ }^{34}$ Secara khusus, Michael Goulder menyatakan bahwa musuh dalam konteks Mazmur 23 adalah musuh dalam konteks militer yakni peperangan untuk menguasai suatu daerah secara politik. ${ }^{35}$ Semua identifikasi di atas dapat digunakan dengan pemahaman bahwa pemazmur mengalami banyak tekanan dari lawan-lawannya yakni berupa tekanan ekonomi, politik, budaya dan agama, namun TUHAN tetap menyertai dengan memberikan kesejahteraan yang berlimpah dengan lengannya yang kuat. ${ }^{36}$ Di sini konsep Allah sebagai Pencipta alam semesta digaungkan oleh pemazmur.

TUHAN juga digambarkan mengurapi pemazmur dengan minyak. Tindakan pengurapan di sini menandai pemazmur adalah seseorang yang dilantik menjadi pejabat pemerintahan kerajaan Israel (Mzm. 45:7; 95:10; 113:2; Ams. 6:6; Luk. 7:46). Ia adalah seseorang yang dipilih dan diberkati TUHAN secara khusus untuk melaksananakan tugas menyatakan syalom di muka bumi. Penggunaan minyak zaitun dalam upacara pengurapan seorang pemimpin Israel menandakan janji Allah untuk selalu memberikan kemakmuran dan kejayaan. ${ }^{37}$ Inilah yang ditegaskan oleh pemazmur "pialaku penuh melimpah". Tuhan memberikan pemeliharaan dan kelimpahan materi bagi pemazmur di hadapan lawan-lawannya. ${ }^{38}$ Tuhan memberi yang terbaik untuk pemazmur dan umat pilihannya.

Berdasarkan bahasan di atas tergambar jelas ada banyak sekali lambang atau simbol pemberian atau penganugerahan ilahi yang menggerakkan perasaan dan pikiran pemazmur, bahwasanya di tengah peperangan (kesulitan) Allah tetap memperhatikan umat dalam setiap

\footnotetext{
${ }^{33}$ Gaebelein, The Expositor to Bible Commentary Vol. V, 218.

${ }^{34}$ T. R Hobss and P.K Jackson, "The Enemy in The Psalms," Biblical Theology Bulletin 21, No. 1 (1991): 22-29, https://journals.sagepub.com/doi/abs/10.1177/014610799102100104.

${ }^{35}$ Michael Goulder, "David and Yahweh in Psalms 23 and 24," Journal for the Study of the Old Testament 30, no. 4 (2006): 463-473.

${ }^{36}$ E. Power, "The Shepherd's Two Rods in Modern Palestine and Some Passages of the Old Testamen," Biblica 9, no. 1 (1928): 441J. Morgenstern, "Psahn 23," Journal of Biblical Literature LXV, No. 1 (1945): 1324..

${ }^{37}$ John F. Walvoord and Roy B. Zuck, The Bible Knowledge Commentary, 8.

${ }^{38} \mathrm{~J}$ Robert Jamieson, "Commentary Practical and Explanatory On The Whole Bible., 416; G. Archer, A Survey of Old Testament Introduction (Chicago: Moody Press, 1964).48Briggs F, Brown, S. R, Driver and C, A, A Hebrew and English Lexicon of the Old Testament (Oxford: The Clarendon Press, 1962).,627; C. A. Briggs, A Critical and Exegetical Commentary on the Book of Psalms (Edinburgh: T \& T Clark, 1927).211",
} 
lini kehidupan. Terlihat ketenangan dari orang saleh meskipun dan dalam pandangan atau pengawasan dari musuh-musuhnya. ${ }^{39}$ Dimensi psikologi (kejiwaan) pemazmur disebutkan sangat tenang walaupun harus makan di hadapan para musuh menghadang. Bahkan pemazmur diyakinkan kemenangan pasti diraih oleh karena Tuhan, digambarkan dengan urapan di atas kepalanya dan piala penuh melimpah merupakan indikasi kuat akan hal tersebut. Kemenangan yang digapai bukan hanya penaklukan terhadap para musuh dalam peperangan akan tetapi penunjukannya sebagai orang yang diurapi (orang pilihan, unggul) sehingga layak untuk jabatan tertentu. Pemazmur menunjukkan kualitas dirinya di hadapan para musuh dalam medan perang dan di antara umat Allah sebagai pribadi yang layak diperhitungkan.

\section{Maz. 23:6}

Pemazmur semakin menegaskan pemeliharaan TUHAN dengan kalimat 'kebajikan dan kemurahan belaka akan mengikuti aku seumur hidupku'. TUHAN diyakini akan setia memberkati pemazmur dengan kebajikan dari kemurahan. Kebajikan (tov) merujuk jiwa yang bahagia, kepuasaan terhadap pemenuhan materi, karakter yang baik, kecerdasan dalam menyelesaikan permasalahan hingga mampu menggapai kesuksesan. Sedangkan kemurahan (khesed) berkaitan dengan relasi yang baik dengan sanak keluarga, teman, rekan kerja, para pelayan, para pemimpin lainnya. Pemazmur percaya TUHAN akan mengaruniakan semuanya itu kepadanya. Pemazmur menyadari bahwa Tuhan adalah baik, penuh kasih setia (khesed). Dia menyertai kemana dia pergi dan menyertainya seumur hidupnya. ${ }^{40}$ Puncak dari kebahagian dan jaminan yang diberikan TUHAN tidak bersifat fana atau sementara akan tetapi jauh dari pada itu semua adalah suatu yang bersifat abadi atau kekal adanya. Robert mengatakan bahwa pemazmur yakin akan kemurahan TUHAN yang menunjukkan berkat rohani bagi pemazmur yang punya kecenderungan untuk lemah secara spiritual. ${ }^{41}$ Di sini pemazmur menunjukkan rasa percaya kepada diri dna TUHAN sehingga ia tidak takut sedikit pun terhadap bahaya. Ayat itu memperlihatkan sesuatu terjadi hanya karena kemurahan dan kebaikan-Nya saja, ketenangan jiwa dan rasa aman diperoleh sebab hadirat TUHAN terus menerus dalam hidupnya.

Daud mengakhiri Mazmur doanya dengan kalimat aku akan diam dalam rumah Tuhan sepanjang masa. Kata diam dalam rumah Tuhan menguak harapan raja Daud untuk memiliki hubungan yang intim menyatu padu dengan Tuhan. ${ }^{42}$ Merunut kajian di atas pada ayat 6 , mendeskripsikan secara runtut diakhir mazmurnya yang memperlihatkan harapan dan doa yang sangat visioner dan imajinatif tentang ungkapan kepercayaan diri pemazmur bahwasanya kebajikan dan kemurahan Allah menyertainya selalu. Malaikat pelindung kembar ini (kebajikan dan kemurahan) akan selalu membersamai pemazmur. ${ }^{43}$ Analogi yang tepat, keba-

\footnotetext{
${ }^{39}$ Charles H. Spurgeon's, Treasury of David, https://www.christianity.com/bible/commentary.php?com=spur\&b=19\&c=23 diunduh tanggal 12 September 2020 jam 23.30 WIB.

${ }^{40}$ Walvoord and Roy B. Zuck, The Bible Knowledge Commentary, 8.

${ }^{41}$ Jamieson, “Commentary Practical and Explanatory On The Whole Bible. ", 416.

${ }^{42}$ Jhon Mac Arthur, The MacArtthur Bible Commentary (Mexico: Thomas Nelson, 2005).11

${ }^{43}$ Spurgeon's, Treasury of David,

https://www.christianity.com/bible/commentary.php?com=spur\&b=19\&c=23 diunduh tanggal 12 September 2020 jam 23.30 WIB.
} 
jikan dan kemurahan diumpamakan seperti malaikat kembar yang akan terus bersamanya untuk mengawasi sepanjang hidupnya baik dalam situasi yang tenang maupun tegang. Pada ujung nyanyian, pemazmur terus mengumandangkan dan menegaskan bahwa tempat terakhir dari perjalanan yang panjang adalah di rumah Tuhan dan akan tinggal untuk selamanya, sebuah monolog akhir profetik yang mengandung asa akan kehidupan eskatologis setelah kehidupan kosmologis.

Berdasarkan kajian analisis teks mendalam di atas, maka akan dipaparkan Mazmur 23 sebagai quantum afirmasi yang digunakan Raja Daud untuk membersihkan warna auranya setiap hari. Eksistensi Mazmur 23 sebagai Mazmur doa Daud berdimensi kalimat penegasan yang menyembuhkan (affirmasi healing) cakra manusia. Melalui pengucapan Mazmur 23 sebagai kalimat doa rutin maka Daud menciptakan gambaran dalam kepalanya tentang segala sesuatu yang baik tentang diri sendiri dan semua yang dipercayai berdampak positif terhadap diri sendiri secara mutlak. Ia menciptakan pikiran tentang kekuatan Tuhan, kekuatan alam semesta, dan kekuatan diri. Ada tindakan untuk memperkenalkan pikiran yang positif dengan mengulangi kalimat positif tersebut secara lisan untuk mengurangi secara perlahan-lahan hingga menghapus pikiran atau energi negatif yang tersimpan dalam setiap cakra tubuhnya. Tindakan pembersihan tersebut memastikan warna aura setiap cakra tubuh memancarkan warna terang mewujud dalam kekuatan mental, kecerdasan intelektual, kecerdasan emosional, kecerdasan sosial yang mencipta kesuksesan dalam hidupnya. Kalimat dalam mazmur 23 yang mengandung energi penyembuhan yang dapat mengikis energi negatif dalam cakra tubuh dan menggantinya dengan energi yang positif dari Tuhan dan alam semesta.

\section{Afirmasi Cakra Dasar (ayat 1)}

Cakra dasar merupakan pusat energi yang mengatur semangat hidup seseorang dalam memenuhi kebutuhan materi tubuh fisik. Setiap orang butuh makanan dalam menyuplai kebutuhan energi dalam beraktivitas. Titik energi ini berada pada ujung ekor manusia. Ketika kebutuhan makanan terpenuhi membuat seseorang semangat, optimis dengan kesehatannnya, memiliki mood yang baik dan optimis. Namun ketika kebutuhan makanan tidak terpenuhi karena finansial keluarga yang menurun, menimbulkan ketakutan yang terbawa hingga mengakibatkan ketidakseimbangan energi dalam cakra dasar. Ada energi putus asa menyelimuti cakra dasar sehingga warna aura menjadi gelap. Sekaitan dengan itu, maka energi putus tersebut patut dihempaskan dengan afirmasi pembersihan.

Secara spiritual kalimat "Tuhan adalah gembalaku, takkan kekurangan aku" merupakan afirmasi membersihkan cakra dasar dengan aura merah yang kotor. Melalui pernyataan ini Daud mengafirmasi Tuhan sebagai pencipta alam semesta yang sempurna. Dalam pernyataan tersebut Daud membuka kesadaran pikiran, perasaan dan tubuh untuk membumi dan terhubung dengan bumi. Ia menegaskan dalam gambaran pikiran kepalanya bahwa ia memiliki semua yang dibutuhkan untuk memenuhi kebutuhan fisiknya. Ia menyukai hidupnya sebagai seorang manusia. Ia membiarkan dirinya berada dalam pemeliharaan alam semesta. Ia menyatu dengan tubuh fisiknya dengan keyakinan bahwa semua baik-baik saja, tidak kekurangan apa pun karena semua telah tersedia di alam semesta.

Ada keyakinan bahwa ia tidak akan miskin, tidak berkekurangan makan dan minum sebagaimana yang ditegaskan dalam kalimat "ia membaringkan aku dipadang yang berumput 
hijau" yang menekankan unsur tanah dari elemen cakra dasar. Dalam statement "membaringkan aku", Daud menunjukkan penerimaan terhadap tubuhnya sebagai manusia yang memiliki perasaan takut, gelisah, kuatir dengan pemenuhan akan makan, minum dan materi lainnya yang tersedia di alam semesta. Daud menerima semua perasaan tersebut dengan damai dan memilih untuk merawat tubuhnya dengan semua materi yang telah Tuhan sediakan di alam semesta. Ada keyakinan bahwa tanah akan selalu mampu memenuhi kebutuhan materinya. Di sini Daud mengaktifkan cakra dasar yang berwarna merah yang mengatur energi tubuh fisik untuk menikmati kehidupan secara materi dan semangat untuk hidup sebagai manusia yang berelasi dengan materi.

\section{Afirmasi Cakra Sakral (ayat 2b-3a)}

Cakra Sakral berpusat di kelamin manusia. Cakra ini merupakan titik energi yang berwarna jingga berperan mengatur kemampuan seseorang untuk mengungkapkan emosi dengan cara sehat, terbuka untuk membagikan perasaan dengan orang lain, adanya hubungan karib dan intim dengan seseorang. Bila cakra ini kotor maka seseorang akan selalu dipenuhi pikiranpikiran yang negatif, dan seseorang akan memiliki cakra sakral berelemen air. Dalam ayat $2 b$ Daud secara terbuka mengafirmasi perasaan intimacy dengan Tuhan dalam kalimat "Ia membimbing aku ke air yang tenang." Tuhan dipercayai membimbingnya ke air yang tenang. Daud mengakui perjalanannya untuk bertemu dengan sumber air di alam semesta sebagai bagian dari arahan Tuhan untuk menerapi pikirannya yang negatif, kuatir dengan kebutuhan materi dan setiap rasa bersalah yang terhadap diri sendiri dan orang lain.

Sapuan air di alam semesta menimbulkan kegembiraan, kenyamanan dan kesenangan hidup. Tubuh kembali bersemangat dengan sejumlah inspirasi unttuk kreatif dalam bekerja untuk memenuhi kebutuhan hidupnya. Pikiran yang kembali tenang, segar karena sapuan dan sentuhan air. Bimbingan Tuhan dalam pertemuan dengan sumber air kehidupan di alam semesta telah menjadi dasar untuk melepaskan pikiran berulang-ulang yang kuatir dan cemas, gelisah tentang kebutuhan material hidupnya. Afirmasi "Ia menyegarkan jiwaku", Daud meminta energi Tuhan untuk memulihkan keinginan, hasrat, gairah, semangat hidup, vitalitas kekuatan fisiknya dan psikisnya. Daud mengafirmasi pikiran positif tentang Tuhan yang berdampak pada pikiran positif terhadap sesama.

\section{Afirmasi Cakra Solar Pleksus (ayat 3b-4a)}

Cakra Solar Pleksus bertempat di pusar manusia yang mengelola keberanian, ketekunan, kekuatan, keadilan, keinginan untuk berhasil dalam setiap pekerjaan. Seseorang memiliki cakra solar yang memancarkan aura kuning terang memiliki energy kecerdasan menguasai pikiran, emosi yang baik sehingga menggapai kesuksesan dalam hidup. Cakra ini berelemen api. Bila cakra ini kotor maka biasanya orang akan terlihat bermental korban, rendah diri, malu, amarah tak terkontrol. Melalui ungkapan "aku tidak takut bahaya sebab Engkau besertaku”, Daud mengafirmasi eksistensi Tuhan yang selalu bersamanya dan selalu menolongnya dari setiap orang berniat jahat kepadanya. Ada usaha menimbun rasa puas terhadap penyertaan Tuhan terhadap dirinya dalam setiap ancaman bahaya yang menghantui setiap saat.

Ia mengafirmasi dirinya untuk berani menerima setiap persoalan yang dihadapi dengan berani tanpa menyalahkan keadaan. Ia pun mengafirmasi dirinya untuk tidak merasa malu dan rendah diri dengan dirinya. Ia mengafirmasi rasa percaya diri dan harga diri yang positif dan 
ideal dalam kehidupan pribadinya dan karirnya. Ia memulihkan energi karismatik dalam dirinya untuk berbicara nyaman berbicara tentang apa pun dengan nyaman dan mampu memberdayakan sesama untuk nyaman dengan kehiduapannya sendiri. Karena keyakinan bahwa Tuhan selalu bersamanya maka ia tidak patut marah, iri, benci kepada orang lain. Ia pun tidak boleh hidup serakah. Sebab marah, iri, benci, hidup serakah menjadi tindakan untuk menarik energi negatif mendiami cakra solar pleksus yang membuatnya berjuang dengan harga diri karena tidak aman dan tidak puas dengan kehidupannya sendiri.

\section{Afirmasi Cakra Jantung (ayat 4b)}

Cakra Jantung yang memancarkan aura hijau emerald mengatur energi cinta kasih, harapan dan kasih sayang, kemampuan berempati dengan dengan sesama. Cakra Jantung berelemen udara. Orang yang memiliki cakra jantung yang bersih mampu berada pada titik memaafkan sepenuh hati orang yang menyakitinya. Cakra ini bisa kotor karena tindakan yang semenamena terhadap diri sendiri dan sesama, tidak peduli dengan Tuhan. Akibatnya, seseorang cenderung marah, bertengkar dengan sesama. Menarik bahwa dalam ungkapan, "gada dan tongkat-MU itulah yang menghibur aku", Daud mendidik diri mengakui rasa cinta, harapan akan kasih sayang Tuhan yang menjadi landasannya untuk berempati dengan orang lain. Daud membuka diri untuk cinta diri yang mendalam dengan menerima cinta dari Tuhan. Daud mengkoneksikan dirinya dengan kekuatan cinta Tuhan yang sangat besar. Daud mengafirmasi ketulusan dan rasa syukur atas kasih Tuhan atas hidupnya serta siap berbelas asih dengan dengan sesama.

\section{Afirmasi Cakra Tenggorokan (ayat 5)}

Cakra tenggorokan merupakan pusat energi komunikasi, kreativitas dan sosialiasasi. Cakra ini bila bersih maka akan memancarkan warna biru muda. Cakra ini mengelola kemampuan ekspresi verbal dengan nyaman dan kreativitas. Individu yang memiliki cakra tenggorokan berwarna biru muda yang kotor ditandai dengan komunikasi yang buruk, menjadi pendengar yang buruk, kesulitan berbicara, suka berteriak dan mendominasi percakapan. Berkaitan dengan itu, Daud sebagai pemimpin dituntut mampu berkomunikasi dan bersosialisasi dengan baik dengan para raja, pemimpin-pemimpin yang menjadi rekan kerja tetapi juga musuh dalam politik. Melalui pernyataan "Engkau menyediakan hidangan bagiku di hadapan lawanku", mengafirmasi energi untuk mampu berkomunikasi dengan orang lain termasuk musuhmusuhnya yang ingin menjegalnya secara diplomatif. Energi ini penting untuk tetap tenang, santai, santun dan tegas ketika berkomunikasi dan bersosialisasi dengan para raja dan pemimpin. Ia pun mengafirmasi kebenaran bahwa Tuhan yang mengurapinya menjadi raja. Oleh karena itu tidak ada alasan untuk gagap bicara dengan para raja dan pemimpin saat itu. Ungkapan "Pialaku penuh melimpah", merupakan kalimat afirmasi energi kreativitas dari Tuhan dalam dirinya untuk mencipta, memproyeksikan gagasan menjadi kenyataan dalam menyejahterakan orang Israel.

\section{Afirmasi Cakra Mata Bathin (ayat 6a)}

Cakra Mata Bathin berwarna nila cerah menandai kemampuan intuisi untuk melihat kebijaksanaan alam semesta. Elemen cakra mata bathin adalah cahaya. Cakra ini terletak di persimpangan alis dan mengatur cakra tenggorokan, cakra jantung, solar pleksus, sakral dan dasar. Seseorang memiliki cakra mata batin yang bersih mampu mendapatkan informasi tentang 
sesuatu secara langsung tanpa melalui indera; dan memiliki wawasan, kreativitas, motivasi hidup dan inspirasi tiada batas. Namun bila tersumbat maka seseorang akan mengalami delusi, depresi, kegelisahan dan paranoia, halusinasi dan skeptisisme. Terkait Mazmur sebagai teks affirmasi healing, pernyataan "kebajikan dan kemurahan belaka akan mengikuti aku", menjadi afirmasi yang menghubungkan raja Daud untuk terhubung dengan kebajikan dan kemurahan energi keberuntungan di alam semesta. Ia membuka diri untuk menerima wawasan imajinasi yang tak terbatas dari alam yang tersedia di alam semesta yang diciptakan Tuhan.

\section{Afirmasi Cakra Makhota (ayat 6b)}

Cakra makhota terletak di ubun-ubun kepala manusia dan menjadi pintu masuk energi ilahi yang dialirkan ke seluruh lapisan cakra di bawahnya. Setiap orang yang cakra mahkotanya bersih memancarkan warna aura ungu dan menampilkan rasa terintegrasi menyatu secara spiritual dengan sang Ilahi yang mencipta alam semesta (pencerahan), mengetahui rahasia alam, memiliki arah dan tujuan hidup yang jelas. Cakra makhota memiliki elemen pemikiran. Orang yang memiliki cakra makhota yang kotor atau tersumbat cenderung menunjukkan sikap depresi, mengasingkan diri, dan tidak mampu belajar dan mengerti. Cakra ini diharapkan selalu bersih sehingga energy ilahi apat diterima oleh seluruh tubuh. Cara membersihkan cakra ini adalah memperbanyak ibadah, mendekatkan diri kepada sang ilahi. Inilah yang nampak dalam ungkapakan afirmasi Daud dalam Mazmur 23 ayat 6b "aku akan diam dalam rumah Tuhan sepanjang masa." Pemazmur menyatakan kesediaan untuk setia belajar Taurat Tuhan, mengerti kebenaran yang mendalam tentang kehidupan, mendapatkan berkat inspirasi ilahi untuk bersikap, berperilaku, berkarya bagi bagi bumi dan seisinya. Melalui kalimat ini Daud mengafirmasi kemenyatuan dengan Tuhan yang di surga, dan kemampuan untuk menikmati berkat Tuhan sepanjang masa. Kalimat tersebut menjadi pemantik energi di cakra makhota untuk selalu bersih dan terang dan terbuka untuk menerima energi ilahi dari Tuhan setiap hari yang dapat disalurkan ke cakra yang lainnya.

\section{Kesimpulan}

Mazmur 23:1-6 tidak salah bila disebut sebagai Mazmur Doa keyakinan dan kepercayaan dari Daud kepada Tuhan. Keberhasilan Daud dalam kepribadian, kepemimpinannya sebagai raja dipengaruhi oleh kalimat afirmasi yang sangat menggema ini. Kalimat-kalimat doa dalam Mazmur 23 mengandung unsur penyembuhan dan penegasan energi dalam ketujuh cakra manusia. Pembacaan teks dalam liturgi ibadah personal dan komunal tentu sangat tepat dilakukan dalam rangka membersihkan setiap cakra dengan energi ilahi yang positif sehingga aura tubuh bersinar terang. Dengan demikian harapan untuk hidup lebih tenang, damai, membumi dan penuh berkat kesuksesan lebih mudah tercapai. Dalam rangka penyembuhan keseluruhan cakra secara personal, Mazmur 23 disarankan untuk dibaca setiap pagi setelah bangun tidur dan malam hari menjelang tidur sebanyak 5, atau 7, atau 11 sesuai kebutuhan kesembuhan masing-masing.

\section{Referensi}

Abineno, J.L. Ch. Mazmur Dan Ibadah. Jakarta: BPK Gunung Mulia, 1991. Archer, G. A Survey of Old Testament Introduction. Chicago: Moody Press, 1964.

Arthur, Jhon Mac. The MacArtthur Bible Commentary. Mexico: Thomas Nelson, 2005. 
B. A. Pareira \&, Marie. Claire Barth. Tafsiran Alkitab: Kitab Mazmur 1-72. Jakarta: BPK Gunung Mulia, 2008.

Benson, Clarence H. Pengantar Perjanjian Lama-Puisi Dan Nubuat”(Ayub-Maleakhi. Malang: Penerbit Gandum Mas, 1983.

Beyer, A.A. Sitompul. \& Ulrich. Metode Penafsiran Alkitab. Jakarta: BPK Gunung Mulia, 2015.

Briggs, C. A. A Critical and Exegetical Commentary on the Book of Psalms. Edinburgh: T \& T Clark, 1927.

Charry, Ellen T. Psalms 1-50. Whasinton: Brazos Press, 2015.

Douglas, J. D. Ensiklopedi Alkitab Masa Kini. Jakarta: Yayasan Bina Kasih /OMF, 1995.

Exell, H.Spence and Joseph S. The Pulpit Commentary, Vol. VIII. Michigan, Grand Rapids: Eerdsmans Publishing, 1977.

F, Brown, S. R, Driver and C, A, Briggs. A Hebrew and English Lexicon of the Old Testament. Oxford: The Clarendon Press, 1962.

Gaebelein, Frans W. The Expositor to Bible Commentary Vol. V. Michigan, Grand Rapids: The Zondervan Publising House, 1991.

Gerstenberger, Erhard S. Psalms, Part I with an Introduction to CuI Tic Poetry. The Forms of Old Testament Literature. Vol. 14. Grand Rapids: Wm. B. Eerdmans Publishing Co, 1988.

Goulder, Michael. "David and Yahweh in Psalms 23 and 24." Journal for the Study of the Old Testament 30, no. 4 (2006): 463-473.

Gunawan, King. Melalui Aura Kenali Potensi Sukses Anda Dalam 10 Detik. Jakarta: PT Elex Media Komputindo, 2010.

Hamilton, Victor P. "The Shepherd Psalm: Psalm 23" (1966).

Heaster, Duncan. Psalm 1-80: A Commentary. Australia: Carelinks, 2018.

Heiser, Michael S. "Does Divine In The Hebrew Bible Demonstrate an Evolution From Polytheism to Monotheism in Israel Religion." JESOT 1, no. 1 (2012): 1-20.

https://books.google.co.id/books?id=CZFNAwAAQBAJ\&pg=PA16\&lpg=PA16\&dq=y ahweh+journal+old+testament\&source $=$ bl\&ots $=0 \mathrm{~B}-$

v0888Rz\&sig=ACfU3U0fw0TYV3jF1FnrFyMDw5F8UlfyNg\&hl=id\&sa=X\&ved=2ah UKEwiR5P6q8_7pAhWEXSsKHfiRALYQ6AEwEXoECAcQAQ\#v=onepage\&q=yah weh journal old.

Houston, Walter J. "The Character of Yhwh and the Ethics of the Old Testament: Is Imitatio Dei Appropriate?" Journal of Theological Studies 58, no. 1 (2007): 1-25.

Jackson, T. R Hobss and P.K. "The Enemy in The Psalms." Biblical Theology Bulletin 21, no. 1 (1991): 22-29. https://journals.sagepub.com/doi/abs/10.1177/014610799102100104.

Jamieson, Robert. “Commentary Practical and Explanatory On The Whole Bible." Michigan: The Zondervan Publising House, 1978.

Marlowe, W. Creighton. "No Fear!: Psalm 23 As A Careful, Conceptual Chiasm." The Asburry Theological Journal 7, no. 1 (2003): 497-516.

Mills, Dag Heward. The Art of Sherperding. America: Lux Verbi.BM, 2010.

Minnich, Deanna M. The Complete Handbook of Quantum Healing : An A-Z Self Healing Guide for Over 100 Common Ailments. America: Red Wheel Weiser, 2011.

Morgenstern, J. "Psahn 23." Journal of Biblical Literature LXV, no. 1 (1945): 13-24.

Murphy, Jhon. The Study of Science Physics : Understanding The Properties of Matter and Energy. New York: Britannica Educational Publishing \& Rosen Publishing, 2015.

Peacock, Heber F. "Translating the Word for "Soul" in the Old Testament." The Bible Translator 27, no. 2 (1976): 216-219.

Pleijel, Richard. “ Translating the Biblical Hebrew Word Nephesh in Light of New Research ." The Bible Translator 70, no. 2 (2019): 154-166. 
Power, E. "The Shepherd's Two Rods in Modern Palestine and Some Passages of the Old Testamen." Biblica 9, no. 1 (1928): 441.

Sontsz Bruce, Stephen. An Introductory Path to Quantum. Mexico: Springers, 2020.

Tesla, Niko. The Problem of Increasing Human Energy. New York: Cosimi, Inc, 2013.

Thomas, D. W. ""Salmawet in the Old Testament." "Journal of Semitic Studies XXII, no. 1 (1962): 1991.

Zuck, John F. Walvoord and Roy B. The Bible Knowledge Commentary. USA-CanadaEngland: Victor Book House, 1978. 